\title{
Right-sided diaphragmatic rupture after blunt trauma. An unusual entity
}

Ramon Vilallonga ${ }^{1 *}$, Vicente Pastor ${ }^{2}$, Laura Alvarez ${ }^{3}$, Ramon Charco ${ }^{4}$, Manel Armengol $^{5}$, Salvador Navarro ${ }^{6}$

\begin{abstract}
Traumatic injuries of the diaphragm remain an entity of difficult diagnosis despite having been recognised early in the history of surgery, especially when it comes to blunt trauma and injuries of the right diaphragm. We report the case of a patient with blunt trauma with right diaphragmatic rupture that required urgent surgical treatment for hepatothorax and iatrogenic severe liver injury. Blunt trauma can cause substantial diaphragmatic rupture. It must have a high index of suspicion for diaphragmatic injury in patients, victims of vehicle collisions, mainly if they have suffered frontal impacts and/or side precipitates in patients with severe thoracoabdominal trauma. The diagnosis can be performed clinically and confirmation should be radiological. The general measures for the management of multiple trauma patients must be applied. Surgery at the time of diagnosis should restore continuity.
\end{abstract}

\section{Introduction}

Traumatic injuries of the diaphragm remain an entity of difficult diagnosis despite having been recognised early in the history of surgery. Sennertus, in 1541, performed an autopsy in one patient who had died from herniation and strangulation of the colon through a diaphragmatic gap secondary to a gunshot wound received seven months earlier [1]. However, these cases remain rare, and difficult to diagnose and care for. This has highlighted some of the aspects related to these lesions, especially when they are caused by blunt trauma and injuries of the right diaphragm $[1,2]$.

\section{Case report}

We report the case of a man of 36 years of age, thrown from a height of 12 meters and was referred to our centre. The patient arrived conscious and oriented, and we began manoeuvring the management of the patient with multiple injuries according to the guidelines of the ATLS (Advanced Trauma Life Support) recommended by the American College of Surgeons. The patient had an unstable pelvic fracture (type B2) with hemodynamic instability and respiratory failure. Patient's Injury Severity Score (ISS) was 38. Pelvis and chest X-rays were

\footnotetext{
* Correspondence: vilallongapuy@hotmail.com

${ }^{1}$ General Surgery Department. Endocrine, bariatric and metabolic Unit. Universitary Hospital Vall d'Hebron. Autonomous University of Barcelona. Spain

Full list of author information is available at the end of the article
}

performed which confirmed the pelvic fracture and pathological elevation of the right hemidiaphragm was observed (Figure 1). We proceeded to stabilise the pelvic fracture and replace fluids, improving hemodynamic status. The patient continued with respiratory failure. For this reason, a chest tube was placed and Computerised Tomography (CT) was performed (Figure 2), showing a ruptured right hemidiaphragm, including chest drain in the right hepatic lobe and occupation of the lesser sac by blood. The patient underwent surgery, finding a right hemidiaphragm transverse rupture with a hepatothorax and an intrahepatic thoracic tube. We performed the suture of the diaphragm and liver packing, moved the patient to the intensive care unit, and after 48 hours, the liver packing was removed without problems. The patient evolved favourably.

\section{Discussion}

Currently, traumatic injuries of the diaphragm remain uncommon, and it is difficult to establish a global impact, but by autopsy studies, the incidence of these injuries range between $5.2 \%$ and $17 \%$ [3]. If we focus on patients with blunt trauma, we find that traumatic injuries of the diaphragm represent only $0.8 \%$ to $1.6 \%$ of the total lesions observed in these patients [4]. However, when we talk about open trauma, these injuries may represent up to $10 \%-15 \%$ of cases $[3,5,6]$.

Road traffic collisions or lateral intrusions into the vehicle are the most frequent causes of diaphragm

\section{Biomed Central}




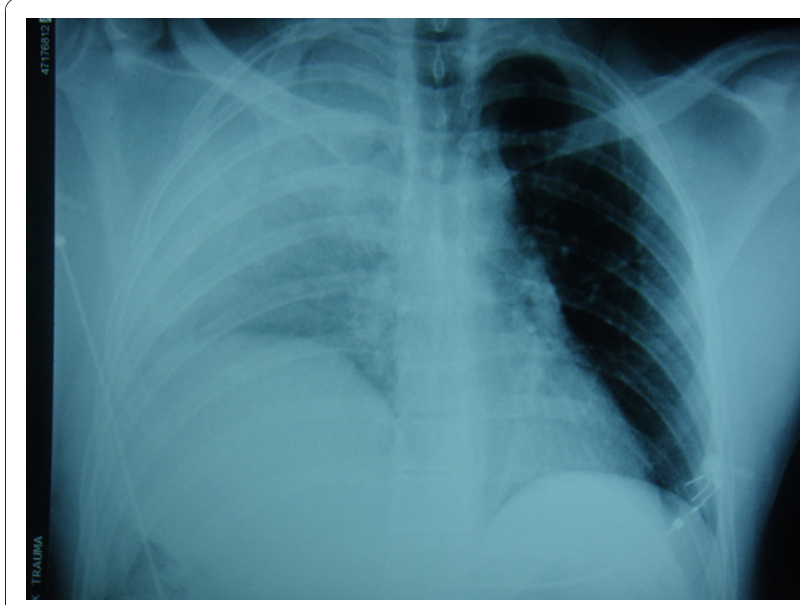

Figure 1 Chest radiograph of the patient showing an elevated right hemidiaphragm

rupture $[1,4,6,7]$. Direct impacts depress the side of the rib cage, and can cause a tear in the diaphragm rib attachments, and even the transverse rupture of the diaphragm [8]. Also, serious slowdown pinching leads to a multiplication by ten times or more to the intra-abdominal pressure, especially if the patient holds his/her breath and contracts the abdominal wall at the time of impact, causing a muscle injury [2].

Classically, there has been a predominance of lesions of the left hemidiaphragm, with a ratio of 25:1. However, most modern series balance this data and show that right hemidiaphragm injuries can represent almost $35 \%$ of all diaphragm injuries [9]. This pattern may explain why the liver develops a protective cushioning pressure, although some authors believe that right hemidiaphragm injuries are associated with increased

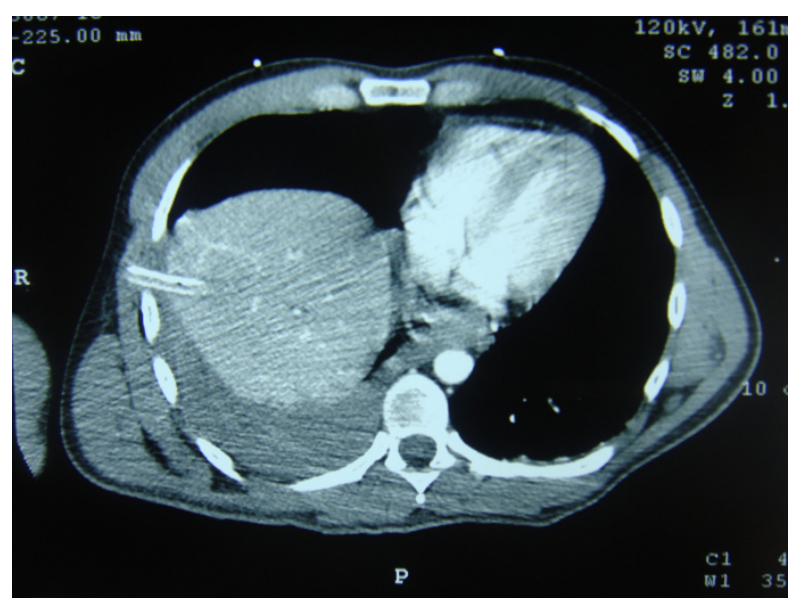

Figure 2 CT scan of the patient where hepatothorax is displayed with the drain inside. mortality so would be undiagnosed, and for this reason would be found in equal proportion at autopsy $[4,6,8]$.

Many authors have reviewed blunt diaphragmatic trauma over a period in their institutions. We do report the major reviewed series to our knowledge in which the do a specific mention to the blunt abdominal trauma associated with diaphragmatic rupture (Table 1).

The clinical presentation is defined by the overall assessment of the patient with multiple injuries. The injury must be suspected when any hemidiaphragm is not seen or not in the correct position in any chest radiograph [15]. The specific signs of diaphragmatic injury on plain radiographs are a marked elevation of the hemidiaphragm, an intrathoracic herniation of abdominal viscera, the "collar sign", demonstration of a nasogastric tube tip above the diaphragm [19]. Also, in the context of high-energy trauma, when combined with a head injury and pelvic fracture, diaphragmatic trauma should be suspected [7]. The diagnosis is based largely on clinical suspicion and a compatible chest radiograph or CT scan [10]. The biggest change in recent years in managing blunt diafragmatic trauma has been the use of high-resolution multislice $\mathrm{CT}$ angiography of the abdomen and chest. This is now a routine test performed in most blunt trauma patients. Ultrasound can also be diagnostic in patients with DR, especially if focused abdominal sonography for trauma (FAST) can be extended above the diaphragm looking for a hemothorax and assessing the diaphragmatic motions (using m-mode if possible). It adds little time to the examination but allows the operator to observe absent diaphragmatic movements, herniation of viscera, or flaps of ruptured diaphragm [19]. However, in the absence of a hernia, it may be difficult to identify traumatic diaphragmatic injury by conventional imaging. Blunt diaphragmatic rupture is often missed during initial patient evaluation. The initial chest radiograph can be negative and a repeat chest radiograph may be necessary. Other diagnostic modalities or even surgical exploration may be required to definitively exclude blunt diaphragmatic rupture. A midline laparotomy is the advocated approach for repair of acute diaphragmatic trauma because it offers the possibility of diagnosing and repairing frequently associated intra-abdominal injuries [11].

Closed diaphragmatic injuries should be treated as soon as possible. Special attention should be given to the placement of thoracic drainage tubes, especially if the radiograph is suspicious [3].

Midline laparotomy is the recommended approach because it allows for an exploration of the entire abdominal cavity $[1,2,4,6,7]$. Routine surgical repair of any diaphragmatic defect is accomplished by interrupted or continuous nonabsorbable sutures and placement of chest tube(s) in the affected thoracic cavity. In 
Table 1 Major series reporting cases in the literature of blunt diaphragmatic rupture

\begin{tabular}{|c|c|c|c|c|c|c|c|}
\hline Author & $\frac{\text { Number of }}{\text { cases }}$ & Trauma type & Location & Associated injuries & $\underline{\text { ISS* }^{*}}$ & Management & Mortality \\
\hline $\begin{array}{l}\text { Chughtai T } \\
\text { et al. [9] }\end{array}$ & $208(1986-2003)$ & Blunt: 208 & $\begin{array}{l}\text { Right: } 135 \\
\text { Left: } 47 \\
\text { Bilateral: } 4\end{array}$ & $\begin{array}{l}\text { Abdomen: liver }(63,5 \%) \text {, spleen }(52,9 \%) \text {, small bowel } \\
\text { mesentery }(46,2 \%) . . \text { Chest: Rib fracture }(75,5 \%) \text {, } \\
\text { pulmonary contusion }(63,0 \%) \text {, hemothorax }(40,4 \%) \text {, } \\
\text { hemopneumothorax }(22,1 \%) \ldots\end{array}$ & Mean ISS 38.0 & $\begin{array}{l}93,3 \% \text { laparotomy } 1,4 \% \\
\text { thoracotomy }\end{array}$ & $\begin{array}{l}60+\text { within } 28 \text { days. Head } \\
\text { injury: } 25 \% \text { Intra- } \\
\text { abdominal bleeding: } \\
23,2 \%\end{array}$ \\
\hline $\begin{array}{l}\text { Ozpolat B } \\
\text { et al. [7] }\end{array}$ & $41(1996-2007)$ & $\begin{array}{l}\text { Blunt: } 20 \\
\text { Penetrating: } 21\end{array}$ & $\begin{array}{l}\text { Right: } 12 \\
\text { Left: } 28 \\
\text { Bilateral: } 1\end{array}$ & $\begin{array}{l}30 \text { (73\%): hemothorax, pneumothorax, liver and rib } \\
\text { fractures }\end{array}$ & Not mentioned. & $85 \%$ operated before $24 \mathrm{~h}$ & $6+(14,6 \%)$ \\
\hline $\begin{array}{l}\text { Lunca S } \\
\text { et al. [12] }\end{array}$ & $61(1992-2003)$ & $\begin{array}{l}\text { Blunt: } 15 \\
\text { Penetrating: } 46\end{array}$ & $\begin{array}{l}\text { Right: } 15 \\
\text { Left: } 45 \\
\text { Bilateral: } 1\end{array}$ & 27 hemorrhagic shock & ISS $=24(6-75)$ & $100 \%$ operated before $12 \mathrm{~h}$ & $9+15$ complications \\
\hline $\begin{array}{l}\text { Cubukçu A } \\
\text { et al. [13] }\end{array}$ & 21 (1995-1998) & $\begin{array}{l}\text { Blunt: } 9 \\
\text { Penetrating: } 12\end{array}$ & $\begin{array}{l}\text { Right: } 12 \\
\text { Left: } 9\end{array}$ & $\begin{array}{l}20 \text { patients with concomitants injuries (Liver in } 10 \\
\text { patients) } 7 \text { patients with signs or symptoms related } \\
\text { to diaphragmatic rupture }\end{array}$ & Not mentioned. & $100 \%$ operated before $24 \mathrm{~h}$ & $3+$ \\
\hline $\begin{array}{l}\text { Dajee A } \\
\text { et al. [14] }\end{array}$ & $48(1973-1978)$ & $\begin{array}{l}\text { Blunt: } 8 \\
\text { Penetrating: } 40\end{array}$ & $\begin{array}{l}\text { Right: }+ \\
\text { Left: }+++ \\
\text { Bilateral: } 1\end{array}$ & $\begin{array}{l}\text { Intra-abdominal injuries involved the spleen, liver, } \\
\text { stomach and colon. } 8 \text { patients herniations of intra- } \\
\text { abdominal contents. }\end{array}$ & Not mentioned & $\begin{array}{l}100 \% \text { laparotomy. No use of } \\
\text { mesh. }\end{array}$ & $3+(6 \%)$ \\
\hline $\begin{array}{l}\text { Tan KK } \\
\text { et al. [16] }\end{array}$ & $14(2002-2008)$ & Blunt: 14 & $\begin{array}{l}\text { Right: } 5 \\
\text { Left: } 9\end{array}$ & $\begin{array}{l}8 \text { Splenic laceration, } 5 \text { hemothorax and lung } \\
\text { injuries, } 4 \text { long bone fracture, } 4 \text { pelvic fracture, } 3 \\
\text { liver laceration, } 3 \text { colonic laceration, } 3 \text { injury major } \\
\text { vessels, } 2 \text { kidney laceration, } 2 \text { small bowel } \\
\text { laceration, } 1 \text { gastric perforation. }\end{array}$ & $\begin{array}{l}\text { Median GCS: } 14 \\
\text { (3-15) Median } \\
\text { ISS: } 41 \text { (14-66). }\end{array}$ & $\begin{array}{l}85,7 \% \text { laparotomy and repair } \\
14,3 \% \text { surgical intensive care } \\
\text { unit. }\end{array}$ & $\begin{array}{l}5+(33 \%) \text { Extensive } \\
\text { injuries }\end{array}$ \\
\hline $\begin{array}{l}\text { Matsevych OY. } \\
{[19]}\end{array}$ & 12 (4 years) & Blunt: 12 & $\begin{array}{l}\text { Right: } 6 \\
\text { Left: } 2 \\
\text { Bilateral: } 1\end{array}$ & $\begin{array}{l}100 \% \text { associated injuries: } 5 \text { hemothorax, } 4 \text { head } \\
\text { injuries, } 3 \text { extremity fracture, } 3 \text { pelvic fracture, } 3 \\
\text { liver laceration, } 3 \text { retroperitoneal hematoma. }\end{array}$ & Not mentioned. & $\begin{array}{l}\text { 100\% laparotomy. } 1 \text { patient } \\
\text { thoracotomy. }\end{array}$ & $\begin{array}{l}3+(25 \%) \text { (Hypovolemic } \\
\text { shck, } 1 \text { brain injury, } 1 \\
\text { cardiac failure) }\end{array}$ \\
\hline $\begin{array}{l}\text { Bergeron E } \\
\text { et al. [20] }\end{array}$ & $\begin{array}{l}160 \text { (April 1, } \\
\text { 1984, to March } \\
\text { 31, 1999) }\end{array}$ & Blunt: 160 & $\begin{array}{l}\text { Right: } 31 \\
\text { Left: } 126 \\
\text { Bilateral: } 3\end{array}$ & $\begin{array}{l}\text { Abdomen: liver }(47 \%) \text {, spleen }(50 \%) \text {, small bowel } \\
\text { mesentery (38\%)... Chest: Rib fracture }(31 \%) \text {, pevi } \\
(41 \%) \text {, other orthopedic }(50 \%) \text {. }\end{array}$ & $\begin{array}{l}\text { ISS }=26.9 \\
(+-11.5)\end{array}$ & $\begin{array}{l}100 \% \text { operated between } \\
60 \text { minutes and } 21.8 \text { days } \\
\text { after injury. } 4 \text { had repair of } \\
\text { diaphragmatic rupture at a } \\
\text { second laparotomy. }\end{array}$ & $14,4 \%$ \\
\hline $\begin{array}{l}\text { Brasel KJ } \\
\text { et al. [21] }\end{array}$ & $\begin{array}{l}32 \text { (January } \\
1987 \text { through } \\
\text { May 1994) }\end{array}$ & Blunt: 32 & $\begin{array}{l}\text { Right: } 7 \\
\text { Left: } 25 \\
\text { Bilateral: } 0\end{array}$ & $\begin{array}{l}\text { Abdomen: liver (47\%), spleen }(50 \%) \text {, small bowel } \\
\text { mesentery (38\%)... Chest: Rib fracture (31\%), pevi } \\
(41 \%) \text {, other orthopedic (50\%). }\end{array}$ & $\mathrm{ISS}=32$ & $\begin{array}{l}100 \% \text { laparotmomy. Sunning } \\
\text { suture all patients and } 1 \\
\text { patient polypropylene mesh } \\
\text { repait. }\end{array}$ & $22,0 \%$ \\
\hline $\begin{array}{l}\text { Shapiro MJ } \\
\text { et al. [22] }\end{array}$ & $\begin{array}{l}20(5 \text { years } \\
\text { period) }\end{array}$ & Blunt: 20 & $\begin{array}{l}\text { Right: } 7 \\
\text { Left: } 14 \\
\text { Bilateral: } 0\end{array}$ & $\begin{array}{l}\text { Shock 16/20; hemo/pneumothorax 15/20; cerebral } \\
\text { injury (12/20); puhnonary contusion 9/20; chest wall } \\
\text { contusion 8/20; hepatic injury 8/20; splenic injury } \\
8 / 20\end{array}$ & $36(11-59)$ & Not mentioned & $25,0 \%$ \\
\hline $\begin{array}{l}\text { Montresor E } \\
\text { et al. [23] }\end{array}$ & $\begin{array}{l}17(1970 \text { to } \\
1995)\end{array}$ & Blunt: 17 & $\begin{array}{l}\text { Right: } 7 \\
\text { Left: } 14 \\
\text { Bilateral: } 0\end{array}$ & $\begin{array}{l}52.6 \% \text { presented at operation with intrathoracic } \\
\text { visceral herniation. }\end{array}$ & Not mentioned. & $\begin{array}{l}8 \text { laparotomy. } 7 \text { laparotomy } \\
\text { and thoracotomy. } 4 \\
\text { thoracotomy }\end{array}$ & $15,6 \%$ \\
\hline
\end{tabular}


Table 1 Major series reporting cases in the literature of blunt diaphragmatic rupture (Continued)

\begin{tabular}{|c|c|c|c|c|c|c|c|}
\hline $\begin{array}{l}\text { Esme H } \\
\text { et al. [24] }\end{array}$ & $\begin{array}{l}14 \text { (January } \\
2000 \text { and June } \\
\text { 2005) }\end{array}$ & $\begin{array}{l}\text { Blunt: } 11 \\
\text { Penetrating: } 3\end{array}$ & $\begin{array}{l}\text { Right: } 4 \\
\text { Left: } 10\end{array}$ & $\begin{array}{l}\text { Multiple associated injuries were observed in } 12 \\
\text { patients (85\%) }\end{array}$ & Not mentioned. & 100\% laparotomy. & Overall: 7\% \\
\hline $\begin{array}{l}\text { Athanassiadi } \mathrm{K} \\
\text { et al. [25] }\end{array}$ & $\begin{array}{l}41(1988 \text { to } \\
1997)\end{array}$ & Blunt: 41 & $\begin{array}{l}\text { Right: } 15 \\
\text { Left: } 24 \\
\text { Bilateral: } 2\end{array}$ & $\begin{array}{l}\text { In } 34 \text { patients (94\%) involving: spleen }(n=18) \text {, rib } \\
\text { fractures }(n=17) \text {, liver }(n=14) \text {, lung }(n=11) \text {, } \\
\text { bowel }(n=7) \text {, kidney }(n=5) \text { and other fractures ( } \\
=21 \text { ) }\end{array}$ & Not mentioned. & $\begin{array}{l}22 \text { laparotomy } 10 \\
\text { thoracotomy } 4 \text { laparo- } \\
\text { thoracotomy }\end{array}$ & $16.6 \%(6 / 36)$ \\
\hline $\begin{array}{l}\text { Gwely NN. } \\
\text { [26] }\end{array}$ & $\begin{array}{l}44(1998 \text { and } \\
2007)\end{array}$ & Blunt: 44 & $\begin{array}{l}\text { Right: } 12 \\
\text { Left: } 30 \\
\text { Bilateral: } 2\end{array}$ & & Not mentioned. & $\begin{array}{l}31 \text { thoracotomy in } 4 \\
\text { laparotomy } 3 \\
\text { thoracolaparotomy }\end{array}$ & $13.2 \%(5 / 38)$ \\
\hline $\begin{array}{l}\text { Yalçinkaya I et } \\
\text { al. [27] }\end{array}$ & $26(1996-2005)$ & Blunt: 26 & $\begin{array}{l}\text { Right: } 8 \\
\text { Left: } 18\end{array}$ & $\begin{array}{l}\text { Multiple associated injuries were observed in } \\
\text { patients (96\%). Thorax herniation of organs (45\%). }\end{array}$ & Not mentioned. & $\begin{array}{l}15 \text { thoracotomy } 7 \\
\text { laparotomy } 4 \text { thoraco- } \\
\text { laparotomy }\end{array}$ & $3+(11.5 \%)$ \\
\hline
\end{tabular}

* Injury Severity Score. 
hemodynamically stable patients with penetrating left thoracoabdominal trauma, the incidence of injury to the diaphragm is very high, and thoracoscopy or laparoscopy is recommended for the diagnosis and repair of a missed diaphragmatic injury. Laparoscopy or videoassisted thoracoscopic surgery (VATS) can be used in hemodynamically stable patients. VATS has greater accuracy (sensitivity and specificity close to 100\%) and helps to avoid the risk of tension pneumothorax [19]. However, we feel that VATS is best reserved for stable patients when intraabdominal and contralateral diaphragmatic injuries are excluded.

Grimes, in 1974, described the three phases of the rupture of the diaphragm: an initial acute phase, at the time of the injury to the diaphragm; [17] a delayed phase associated with transient herniation of the viscera, thus accounting for absent or intermittent nonspecific symptoms; and the obstruction phase involving the complication of a long-standing herniation, manifesting as obstruction, strangulation and posterior rupture [18]. The typical organs that herniate into the thoracic cavity include the stomach, spleen, colon, small bowel and liver, Repair with non-absorbable simple sutures is adequate in most cases, and the use of mesh should be reserved for chronic and large defects. Thus, all surgeons must be vigilant during any exploratory laparotomy to exclude any associated diaphragmatic injury.

Mortality strictly related to diaphragmatic rupture is minimal, and is usually caused by the associated injuries. The most common causes of death reported in the literature are shock, multiple organ failure and head injuries [9]. Outcomes of acute diaphragmatic hernia repair are largely dictated by the severity of concomitant injuries, with the Injury Severity Score being the most widely recognised predictor of mortality. Delayed diagnosis may increase mortality by up to $30 \%$ [8]. The rate of initially missed diaphragmatic ruptures or injuries in nonoperatively managed patients, therefore, ranges from 12 to $60 \%$ [3]. Blunt diafragmatic rupture can easily be missed in the absence of other indications for prompt surgery, where a thorough examination of both hemidiaphragms is mandatory. A high index of suspicion combined with repeated and selective radiologic evaluation is necessary for early diagnosis. Acute diaphragmatic hernia is a result of diaphragmatic injury that accompanies severe blunt or penetrating thoracoabdominal trauma. It is frequently diagnosed early on the trauma by chest radiograph or CT scan of the chest. Non-adverted diaphragmatic injury resulting from the chronic phase of a diaphragmatic hernia will probably require surgery to repair the defect.

\section{Conclusions}

Blunt diaphragmatic rupture can lead to important morbidity and mortality. It is a rare condition, usually masked by multiple associated injuries, which can aggravate the condition of patients. Therefore, there should be a high index of suspicion for diaphragmatic injury in those patients who are victims of vehicle collisions, especially if they have suffered frontal and/or lateral impacts, which have resulted in severe thoracoabdominal trauma. The diagnosis can be made clinically and radiologically. The general measures for the management of multiple trauma patients must be applied. Surgery at the time of diagnosis should restore continuity.

\section{Acknowledgement of financial support}

The authors acknowledge of the Dr. Ramon Vilallonga Foundation for its financial support in carrying out this work. http://www.

fundacioramonvilallonga.org

\section{Author details}

'General Surgery Department. Endocrine, bariatric and metabolic Unit. Universitary Hospital Vall d'Hebron. Autonomous University of Barcelona. Spain. ${ }^{2}$ General Surgery Department. Universitary Hospital Vall d'Hebron. Autonomous University of Barcelona. Spain. ${ }^{3}$ HBP Surgery and Transplants Department. Universitary Hospital Vall d'Hebron. Autonomous University of Barcelona. Spain. ${ }^{4}$ HBP Surgery and Transplants Department. Universitary Hospital Vall d'Hebron. Autonomous University of Barcelona. Spain. ${ }^{5}$ General Surgery Department. Universitary Hospital Vall d'Hebron. Autonomous University of Barcelona. Spain. ${ }^{6}$ General Surgery Department. Universitary Hospital Parc Tauli. Autonomous University of Barcelona. Spain.

\section{Authors' contributions}

VR has take care of the patient and has draft the manuscript. PV, AL, CR helped to the clinical assessment and draft of the manuscript. CR, AM and NS have been involved in drafting the manuscript or revising it critically for important intellectual content. All authors read and approved the final manuscript.

\section{Competing interests}

Dr. Ramon Vilallonga is president of the Dr. Vilallonga Foundation. The rest of authors, declare that they have no competing interests.

Received: 27 November 2010 Accepted: 18 January 2011

Published: 18 January 2011

\section{References}

1. Asencio JA, Demetriades D, Rodriguez A: Injury to the diaphragm. In Trauma. 4 edition. Edited by: en Moore EE, Mattox KL, Feliciano DV. McGraw-Hill, New York; 2000:603-632.

2. Favre JP, Cheynel N, Benoit N, Favoulet P: Traitement chirurgical des ruptures traumatiques du diaphragme. Encycl. Méd. Chir. (Elsevier, Paris-France), Techniques Chirurgicales- Appareil digestif, Paris 2005, 2:235-345.

3. Reber PU, Schmied B, Seiler CA, Baer HU, Patel AG, Büchler MW: Missed diaphragmatic injuries and their-long term sequelae. J Trauma 1998, 44:183-188.

4. Mansour KA: Trauma to the diaphragm. Chest Surg Clin N Am 1997, 7:373-383.

5. Scharff JR, Naunheim KS: Traumatic diaphragmatic injuries. Thorac Surg Clin 2007, 17:81-5.

6. Rosati C: Acute traumatic injury of the diaphragm. Chest Surg Clin N Am 1998, 8:371-379. 
7. Ozpolat B, Kaya O, Yazkan R, Osmanoğlu G: Diaphragmatic injuries: a surgical challenge. Report of forty-one cases. Thorac Cardiovasc Surg 2009, 57:358-62.

8. Boulanger BR, Mizman DP, Rosati C, Rodriguez A: A comparision of right and left blunt traumatic diaphragmatic rupture. J Trauma 1993, 35:255-260.

9. Chughtai T, Ali S, Sharkey P, Lins M, Rizoli S: Update on managing diaphragmatic rupture in Blunt trauma: a review of 208 consecutive cases. Can J Surg 2009, 52:177-81.

10. Ho ML, Gutierrez FR: Chest radiography in thoracic polytrauma. AJR Am J Roentgenol 2009, 192:599-612.

11. Hanna WC, Ferri LE: Acute traumatic diaphragmatic injury. Thorac Surg Clin 2009, 19:485-9.

12. Lunca S, Romedea NS, Moroşanu C: Traumatic rupture of the diaphragm: diagnostic considerations, prognostic factors, outcomes. Rev Med Chir Soc Med Nat lasi 2007, 111:416-22.

13. Cubukçu A, Paksoy M, Gönüllü NN, Sirin F, Dülger M: Traumatic rupture of the diaphragm. Int J Clin Pract 2000, 54:19-21.

14. Dajee A, Schepps D, Hurley EJ: Diaphragmatic injuries. Surg Gynecol Obstet 1981, 153:31-2

15. ATLS: Advanced Trauma Life Support for Doctors. American College of Surgeons, 82008

16. Tan KK, Yan ZY, Vijayan A, Chiu MT: Management of diaphragmatic rupture from blunt trauma. Singapore Med J 2009, 50:1150-3.

17. Grimes OF: Traumatic injuries of the diaphragm. Diaphragmatic hernia. Am J Surg 1974, 128:175-181

18. Goh BK, Wong AS, Tay KH, Hoe MN: Delayed presentation of a patient with a ruptured diaphragm complicated by gastric incarceration and perforation after apparently minor Blunt trauma. Canadian Journal of Emergency Medicine 2004, 6:277-280

19. Matsevych OY: Blunt diaphragmatic rupture: four year's experience. Hernia 2008, 12:73-8.

20. Bergeron $E$, Clas D, Ratte $S$, Beauchamp G, Denis R, Evans D, Frechette $P$, Martin M: Impact of deferred treatment of Blent diaphragmatic rupture: a 15-year experience in six trauma centers in Quebec. J Trauma 2002. 52:633-40

21. Brasel K, Borgstrom DC, Meyer P, Weigelt JA: Predictors of outcome in Blent diaphragm rupture. J Trauma 1996, 41:484-7.

22. Shapiro MJ, Heiberg E, Durham RM, Luchtefeld W, Mazuski JE: The unreliability of CT scans and initial chest radiographs in evaluating blunt trauma induced diaphragmatic rupture. Clin Radiol 1996, 51:27-30.

23. Montresor E, Mangiante G, Vassia S, Barbosa A, Attino M, Bortolasi L, Nifosi F, Modena S, Puchetti V: [Rupture of the diaphragm caused by closed trauma. Case contributions and review of the literature.]. Ann Ital Chir 1997, 68:297-303, discussion 303-5. Italian.

24. Esme H, Solak O, Sahin DA, Sezer M: Blunt and penetrating traumatic ruptures of the diaphragm. Thorac Cardiovasc Surg 2006, 54:324-7.

25. Athanassiadi K, Kalavrouziotis G, Athanassiou M, Vernikos P, Skrekas G, Poultsidi A, Bellenis I: Blunt diaphragmatic rupture. Eur I Cardiothorac Surg 1999, 15:469-74

26. Gwely NN: Outcome of blunt diaphragmatic rupture. Analysis of 44 cases. Asian Cardiovasc Thorac Ann 2010, 18:240-3.

27. Yalçinkaya I, Kisli E: Traumatic diaphragmatic rupture: results of the chest surgery clinic. Ulus Travma Acil Cerrahi Derg 2008, 14:221-5.

doi:10.1186/1749-7922-6-3

Cite this article as: Vilallonga et al: Right-sided diaphragmatic rupture after blunt trauma. An unusual entity. World Journal of Emergency Surgery 2011 6:3.

\section{Submit your next manuscript to BioMed Central and take full advantage of:}

- Convenient online submission

- Thorough peer review

- No space constraints or color figure charges

- Immediate publication on acceptance

- Inclusion in PubMed, CAS, Scopus and Google Scholar

- Research which is freely available for redistribution 